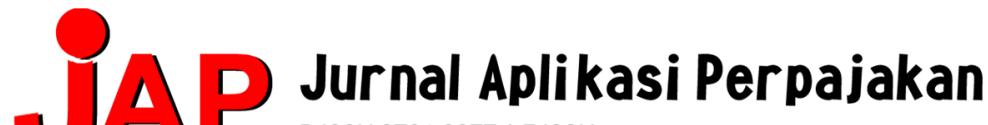

P-ISSN 2721-3277 | E-ISSN

\section{INTENSIFIKASI PAJAK KENDARAAN BERMOTOR (PKB) DALAM RANGKAMENINGKATKAN PENDAPATAN ASLI DAERAH (PAD) PADA BADAN PENGELOLAAN PENDAPATAN DAERAH (BAPPENDA) PROVINSI NTB}

\author{
Abdul Manan \\ Fakultas Ekonomi dan Bisnis Universitas Mataram \\ abdmanan@unram.ac.id \\ Sri Hidayati \\ Fakultas Ekonomi dan Bisnis Universitas Mataram \\ sriehidayati@icloud.com
}

\begin{abstract}
ABSTRAK
Salah satu jenis pajak daerah yang memiliki potensi yang semakin meningkat seiring dengan perkembangan teknologi dan perekonomian masyarakat serta kebutuhan masyarakat adalah Pajak Kendaraan Bermotor (PKB). Sehingga Dalam melaksanakan pemungutan pajak kendaraan bermotor (PKB) dan upaya meningkatkan Pendapatan Asli Daerah (PAD) juga dibutuhkan kesadaran dari masyarakat dalam membayar pajak. Sehingga dalam Praktek Kerja Lapangan (PKL) ini penulis mengambil judul "Intensifikasih Pajak Kendaraan Bermotor (PKB) Dalam Rangkan Meningkatkan Pendapatan Asli Daerah (PAD) Pada Badan Pengelolaan Pendapataan Daerah (BAPPENDA) Provinsi NTB".

Tujuan dari pelaksanaan Praktek Kerja Lapangan (PKL) adalah untuk mengetahui Intensifikasih Pajak Kendaraan Bermotor dalam Rangka Meningkatkan Pendapatan Asli Daerah (PAD) pada Badan Pengelolaan Pendapatan Daerah Provinsi NTB dengan teori-teori atau ketentuan standar yang berlaku umum.

Kegiatan Praktek Kerja Lapangan (PKL) yang dilakukan pada Badan Pengelolaan Pendapatan Daerah Provinsi NTB dilaksanakan selama 1.5 bulan yang dilaksanakan pada tanggal 3 Februari - 18 Maret 2020. Adapun kegiatan yang dilakukan selama PKL yaitu memahami peraturan-peraturan daerah dan mempelajari bagaimana Intensifikasi Pajak Kendaraan Bermotor (PKB) Dalam Rangka Meningkatkan Pendapatan Asli Daerah (PAD) secara mendalam serta membantu untuk mengonfirmasi Wajib Pajak yang menunggak membayar pajakkendaraan bermotor dan membantu mensosialisasikan program unggulanBAPPENDA.
\end{abstract}

Kata kunci: Intensifikasi Pajak, Pendapatan Asli Daerah (PAD)

\section{PENDAHULUAN}

Pajak daerah merupakan sumber pembiayaan terbesar bagi daerah dalam rangka meningkatkan penerimaan daerah. Pajak daerah adalah pajak yang dipungut oleh pemerintah daerah (Provinsi, Kabupaten/Kota) yang diatur berdasarkan UndangUndang No. 18 tahun 1997 tentang pajak daeah dan retribusidaerah. Salah satu jenis pajak daerah yang memiliki potensi yang semakin meningkat seiring dengan perkembangan teknologi dan perekonomian masyarakat serta kebutuhan masyarakat adalah Pajak Kendaraan Bermotor (PKB). Pajak Kendaraan Bermotor (PKB) merupakan salah satu jenis pajak provinsi yang diatur dalam Undang-undang Nomor 28 tahun 2009 Pasal 3 tentang Pajak Daerah dan Retribusi Daerah. Berdasarkan undang-undang tersebut pajak kendaraan bermotor adalah pajak atas kepemilikan dan atau 
penguasaan atas kendaraan bermotor. Pengenaan Pajak Kendaraan Bermotor didasarkan pada Undang-undang Nomor 28 tahun 2009 Pasal 3-8. Pemerintah dan masyarakat memiliki peran yang sama pentingnya dalam menentukan bagaimana seharusnya pajak diterapkan sehingga pemenuhan kewajiban perpajakan dapat dilaksanakan sesuai peraturan yang berlaku. Dalam melaksanakan pemungutan pajak kendaraan bermotor (PKB) dan upaya meningkatkan Pendapatan Asli Daerah (PAD) juga dibutuhkan kesadaran dari masyarakat dalam membayar pajak.

Bappenda Provinsi NTB memiliki ilustras yang sangat penting untuk menjaga nilai jual kendaraan bermotor, dari jumlah pajak kendaraan bermotor di wilayah NTB 5 tahun terakhir yaitu:

Tabel 1. Target, Realisasi, dan Capaian Penerimaan Pajak Kendaraan Bermotor tahun 2015-2019.

\begin{tabular}{c|c|c|c}
\hline Tahun & Target & Realisasi & Persen \\
\hline 2016 & $248,153,000,000$ & $269,187,973,631$ & $108.48 \%$ \\
\hline 2017 & $311,893,723,935$ & $324,423,070,254$ & $104.02 \%$ \\
\hline 2018 & $362,500,000,000$ & $389,092,415,685$ & $107.34 \%$ \\
\hline 2019 & $407,690,000,000$ & $437,162,593,976$ & $107.23 \%$ \\
\hline 2020 & $407,690,000,000$ & 520.080 .000 .000 & $112,99 \%$ \\
\hline
\end{tabular}

sumber: Kantor Bappenda Provinsi NTB, 2020.

Subjek pajak PKB dilihat dari berapa banyak yang rajin membayar pajak dan yang tidak membayar pajak sehingga dapat diketahui dalam tabel berikut bahwa yang aktif membayar pajak lebih banyak daripada yang tidak membayar pajak.

Tabel 2. Data yang Aktif Membayar Pajak dan TIdak Aktif MembayarPajak

\begin{tabular}{l|c}
\hline \multicolumn{1}{c|}{ Kendaraan Bermotor (Persen) } & PKB \\
\hline Daftar Ulang Aktif (89\%) & $289,625,836,758$ \\
\hline Daftar Ulang Tidak Aktif (24\%) & $61,003,070,251$ \\
\hline
\end{tabular}

Sumber: Kantor Bappenda Provinsi NTB, 2020.

Sehubungan dengan wajip pajak yang kurang patuh terhadap kewajiban membayar pajak, Bappenda NTB melakukan barbagai upayah untuk meningkatkan Pendapatan Asli Daerah. Upaya yang dilakuakan oleh pemerintah NTB khusunya Bappenda yaitu menyediakan pelayanan yang memudahakan masyarakat membayar pajak, Pelayanan tersebut yaitu samsat keliling, samsat delivery dan samsat zero waste

Salah satu kebijakan Intensifikasih pajak adalah kegiatan yang dilakukan untuk menambah jumlah penerimaannya dari wajib pajak yang sudah terdaftar sebagai wajib pajak daerah. Sedangkan proses pelaksanaan kegiatan intensifikasi pajak daerah dimulai dari melakukan pemembinaan, sosialisasi peraturan terkait pajak daerah, pengawasan sekaligus melakukan pemeriksaan dalam rangka meningkatkan kesadaran dan kepatuhan wajib pajak dalam melakukan kewajiban perpajakan daerahnya sesuai dengan peraturan dan ketentuan yang berlaku dan juga khususnya untuk peningkatan penerimaan pajak daerah.

\section{TUJUAN}

1. Untuk mengetahui bagaimana Intensifikasih Pajak Kendaraan Bermotor (Pkb) dalam rangka meningkatkan Pendapatan Asli Daerah (Pad) pada kantor Badan Pengelolaan Pendapatan Asli Daerah (Bappenda) Provinsi NTb

2. Untuk mengetahui pencapaian target pajak daerah yang di pungut dari Pajak Kendaraan Bermotor (Pkb) 


\section{TELAAH LITELATUR DAN PENGEMBANGAN HIPOTESIS}

\section{Pengertian Pajak}

Berikut adalah definisi pajak yang telah dikemukakan oleh pakar, yang satu sama lain pada dasarnya memiliki tujuan yang sama yaitu merumuskan pengertian pajak sehingga mudah di pahami. Perbedaan hanya terletak p/ada sudutpandang yang digunakan oleh masing-masing pihak pada saat merumuskan pengertian pajak menurut Ketentuan Umum dan Tata Cara Perpajakan (KUP) Pasal 1 yang berbunyi:

"Pajak adalah kontribusi wajib kepada negara yang terutang oleh orang pribadi atau badan yang bersifat memaksa berdasarkan undang-undang dengan tidak mendapatkan imbalan secara langsung dan digunakan untuk keperluan negara bagi sebesar-besarnya kemakmuran rakyat"

Beberapa para ahli memberikan ulasan tentang pajak. Kutipan beberapa pengertian pajak yang dikemukakan pra ahli sebagai berikut: (Mardiasmo,2011)

a) Menurut Rochmat Soemitro

Pajak adalah iuran rakyat kepada kas negara berdasarkan undang-undang (yang dapat dipaksakan) dengan tidak mendapat jasa timbal balik (kontraprestasi) yang langsung dapat ditunjukkan dan yang di gunakan untuk membayar pengeluaran umum.

b) Menurut S.I Djajadiningrat

Pajak adalah suatu kewajiban menyerahkan sebagian harta kekayaan kepada kas negara disebabkan suatu keadaan, kejadian dan perbuatan yangmemberikan kedudukan tertentu, tetapi bukan sebagai hukuman menurut peraturan yang ditetapkan pemerintah serta dapat dipaksakan, tetapi tidak adajasa timbal balik dari negara secara langsung, untuk memelihara kesejahteraan umum.

c) Menurut R. Santoso Brotodiharjo

Pajak adalah peralihan kekayaan dari pihak rakyat kepada kas negara untuk membiayai pengeluaran rutin "surplus" nya digunakan untuk "public saving"yang merupakan sumber utama untuk membiayai "public investment".

Dari definisi tersebut dapat disimpulkan bahwa pajak memiliki unsur-unsur:

a) Iuran dari rakyat untuk negara artinya yang berhak memungut pajak hanyalah negara. Iuran tersebut berupa uang (bukan barang)

b) Berdasarkan undang-undang artinya pajak dipungut berdasarkan atau dengan ketentuan undang-undang serta aturan pelaksanaannya

c) Tanpa jasa timbal balik atau kontraprestasi dari negara yang secara langsung

d) Digunakan untuk membiayai pengeluaran-pengeluaran yang bermanfaat bagi masyarakat luas.

\section{Fungsi Pajak}

Pajak mempunyai dua fungsi yaitu menurut: (Mardiasmo, 2011)

1. Fungsi budgetair (anggaran atau penerimaan)

Adalah sebagai sumber dana bagi pemerintah untuk membiayai pengeluaranpengeluaran

2. Fungsi regulerend (mengatur)

Adalah sebagai alat untuk mengatur atau melaksanakan kebijakan pemerintah dalam bidang sosail dan ekonomi.

\section{Jenis-jenis pajak}

Pajak dapat dikelompokkan dalam 3 kelompok yaitu: (Mardiasmo, 2011):

1. Menurut golongan

a. Pajak Langsung 
Pajak Langsung yaitu, pajak yang harus dipikul sendiri oleh Wajib Pajakdan tidak dapat dibebankan atau dilimpahkan kepada orang lain. Contoh : Pajak Penghasilan

b. Pajak Tidak Langsung yaitu, pajak yang pada akhirnya dapat dibebankan atau dilimpahkan kepada orang lain.Contoh : Pajak Pertambahan Nilai.

2. Menurut sifatnya

a. Pajak Subjektif, yaitu pajak yang berpangkal atau berdasarkan pada subjeknya, dalam memperhatikan keadaan diri wajib pajak. Contoh: Pajak Penghasilan.

b. Pajak Objektif, yaitu pajak yang berpangkal pada objeknya, tanpa memperhatikan keadaan diri Wajib Pajak. Contoh: Pajak Pertambahan Nilai dan Pajak Penjualan atas Barang Mewah.

3. Menurut Lembaga Pemungutnya

a. Pajak Pusat

Pajak Pusat yaitu, pajak yang dipungut oleh pemerintah pusat dan digunakan untuk membiayai rumah tangga negara. Contoh: PPh, PPN, dan Pajak Penjualan atas Barang Mewah, dan Bea Materai

b. Pajak Daerah

Pajak Daerah yaitu, pajak yang dipungut oleh Pemerintah Daerah dan digunakn untuk membiayai rumah tangga daerah, pajak daerah yaitu:

1) Pajak Provinsi:

a) Pajak Kendaraan Bermotor (PKB)

b) Pajak Bahan Bakar Kendaraan Bermotor (PBBKB)

c) Pajak Bea Balik Nama Kendaraan Bermotor (PBBNKB)

d) Pajak Air Permukaan (PAP)

e) Pajak Rokok.

2) Pajak Kabupaten/Kota terdiri dari:

a) Pajak Hotel

b) Pajak Restaurant

c) Pajak Hiburan

d) Pajak Reklame

e) Pajak Penerangan Jalan

f) Pajak mineral Bukan Logam dan Batuan

g) Pajak Parkir

h) Pajak Air Tanah

i) Pajak Sarang Burung Walet

j) Pajak Bumi dan Bangunan Perdesaan dan Perkotaan

k) Bea Perolehan Hak atas Tanah dan Bangunan.

\section{Unsur-unsur Pajak}

Secara umum terdapat 4 unsur utama pajak berdasarkan sistem perpajakan di Indonesia yakni subjek pajak, wajib pajak, objek pajak, dan juga tarif pajak. Berikut merupakan penjelasan mengenai unsur-unsur pajak dan pengertian lengkapnya.

1. Subjek pajak

Unsur pajak yang utama adalah subjek pajak. Pengertian subjek pajak yang dimaksud disini adalah orang atau badan yang dibebani pajak yang diatur dalam undang-undang. Orang yang telah memenuhi syarat dikenakan pajak termasuk dalam subjek pajak, misalnya adalah individu seperti pengusaha, pegawai atau pembisnis serta juga badan usaha seperti lembaga atau perusahaan tertentu.

2. Wajib pajak

Wajib pajak juga termasuk salah satu unsur-unsur pajak. Pengertian wajib pajak 
dalam sistem pajak diindonesia adalah orang atau badan yang menurut undangundang memiliki kewajiban seperti mendapatkan atau mencari nomor pokok wajib pajak (NPWP) di Direktorat Jendral Pajak (Dirjen Pajak).

3. Objek pajak

Unsur pajak yang berikutnya adalah objek pajak. Pengertian objek pajak merupakan benda atau barang yang menjadi sasaran pajak.

4. Tarif pajak

Pengertian tarif pajak yang dimaksud disini adalah pengenaan besarnya pajakyang harus dibayarkan subjek pajak atas objek pajak yang menjaditanggungannya.

\section{Sistem Pemungutan Pajak}

Dalam memungut Pajak dikenal beberapa sistem pemungutan, yaitu: (Mardiasmo, 2011)

1. Official Assessment System

Adalah suatu sistem pemungutan yang member wewenang kepada pemerintah (fiskus) untuk menentukan besarnya pajak yang terutang oleh Wajib Pajak. ciricirinya:

a. Wewenang untuk menentukan besarnya pajak terutang ada pada fiskus

b. Wajib Pajak bersifat pasif

c. Utang pajak timbul setelah dikeluarkan surat ketetapan pajak oleh fiskus.

2. Self Assessment System

Adalah suatu sistem pemungutan pajak yang member wewenang kepada wajib pajak untuk menentukan sendiri besarnya pajak yang terutang.

Ciri-cirinya:

a. Wewenang untuk menentukan besarnya pajak terutang ada pada WajibPajak sendiri

b. Wajib Pajak aktif, mulai dari menghitung, menyetor dan melaporkan sendiri pajak yang terutang,

C. Fiskus tidsk ikut campur dan hanya mengawasi

3. With Holding System

Adalah suatu sistem pemungutan pajak yang member wewenang kepada pihak ketiga (bukan fiskus dan bukan Wajib Pajak yang bersangkutan) untukmenentukan besarnya pajak yang terutang oleh Wajib Pajak.

\section{Tata Cara Pemungutan Pajak}

Tata cara pemungutan pajak dapat dilakukan berdasarkan 3 stelsel. menyatakan bahwa tata cara pemungutan pajak terdiri dari: (Mardiasmo, 2011)

1. Stelsel Nyata/Rill (riel stelsel) Yaitu pengenaan pajak didasarkan pada (objek penghasilan nyata) sehingga pemungutannya baru dapat dilakukan pada akhir tahun pajak, yakni setelah penghasilan yang sesungguhnya diketahui. Kelebihan: pajak dikenakan lebih realistis. Kelemahan: pajak baru dikenakan akhir periode (setelah penghasilan riil diketahuai)

2. Stelsel Anggapan (fictieve stelsel) Pengenaan pajak didasarkan pada suatu anggapan yang diatur oleh undang-undang. Misalnya, penghasilan suatu tahun dianggap sama dengan tahun sebelumnya, sehingga pada awal tahun pajak sudah dapat ditetapkan besarnya pajak yang terutang untuk tahun pajak berjalan.

3. Stelsel Campuran adalah Pada awal tahun, besarnya pajak dihitung berdasarkan anggapan, kemudianpada akhir tahun pembayaran didasarkan dan disesuaikan dengan keadaan sebenarnya. 


\section{Pajak Daerah}

\section{Pengertian Pajak Daerah}

Pajak daerah adalah pajak yang dipungut oleh Pemerintah Daerah Provinsi, Kabupaten, Kota) yang diatur berdasarkan peraturan daerah masing- masing dan hasil pemungutannya digunakan untuk pembiayaan rumah tangga daerah. Sedangkan menurut Undang-Undang No. 18 tahun 1997 tentang pajak daerah dan retribusi daerah sebagimana di ubah terakhir dengan undang-undang No. 28 tahun 2009, pajak daerah adalah kontribusi wajib kepada daerah yang terutang oleh orang pribadi atau badan yang bersifat memaksa berdasarkan Undang-Undang dengan tidak mendapatkan imbalan secara langsung dan digunakan untuk keperluan daerah bagi sebesar-sebesarnya kemakmuran rakyat. Pajak daerah dapat dipaksakan berdasarkan peraturan perundang-undangan yang berlaku, dimana hasil digunakan untuk membiayai penyelenggaraan pemerintah dan pembangunan daerah.

\section{Pembagian Pajak Daerah}

Pajak daerah dibagi menjadi 2 bagian, yaitu: (Mardiasmo, 2011)

1. Pajak Provinsi

Adalah iuran wajib yang dilakukan oleh pemerintah daerah provinsi kepada orang pribadi atau badan tanpa imbalan langsung yang seimbang yang dapatdipaksaan berdasarkan peraturan perundang-undangan yang berlaku, yang digunakan untuk membiayai penyelenggaraan pemerintah daerah provinsi sebatas pemberian kewenangan untuk melaksanakan otonomi daerah masing-masing.

Yang termasuk pajak provinsi sebagai berikut:
a) Pajak Kendaraan Bermotor
b) Pajak Bea Balik Nama Kendaraan Bermotor
c) Pajak Bahan Bakar Kendaraan Bermotor
d) Pajak Air Permukaan
e) Pajak Rokok

2. Pajak Kabupaten/Kota

Yaitu iuran wajib yang dilakukan oleh pemerintah daerah kabupaten/kota kepada orang pribadi atau badan tanpa imbalan langsung yang seimbang, yang dapat dipaksakan berdasarkan perundang-undangan yang berlaku, dan digunakan untuk membiayai penyelenggaraan pemerintah daerah atau kabupaten sebatas pemberian kewenangan untuk melaksanakan otonomi daerah.

Yang termasuk pajak kabupaten/kota antara lain:
a. Pajak Hotel
b. Pajak Restauran
c. Pajak Hiburan
d. Pajak Reklame
e. Pajak Penerangan Jalan
f. Pajak Mineral Bukan Logam dan Bantuan
g. Pajak Parkir
h. Pajak Air Tanah
i. Pajak Sarang Burung Walet
j. Pajak Bumi dan Bangunan Perdesaan dan Perkantoran
k. Bea Perolehan Hak atas Tanah dan Bangunan.

\section{Ciri-Ciri Pajak Daerah}

Berikut ini ciri-ciri pajak daerah yang membedakannya dengan pajak pusat (Mardiasmo,2020):

1. Pajak daerah bisa berasal dari pajak asli daerah atau pajak pusat yang diserahkan ke daerah sebagai pajak daerah. 
2. Pajak daerahhanya dipungut diwilayah administrasi yang dikuasainya.

3. Pajak daerah digunakan untuk membiayai urusan/pengeluaran untuk pembangunan dan pemerintah daerah.

4. Pajak daerah dipungut berdasarkan peraturan daerah (PERDA) dan undangundang sehingga pajaknya dapat dipaksakan kepada subjek pajaknya.

\section{Pajak Kendaraan Bermotor (PKB)}

\section{Pengertian Pajak Kendaraan Bermotor (PKB)}

Pajak Kendaraan Bermotor adalah pajak atas kepemilikan dan atas penguasaan kendaraan bermotor. Kendaraan bermotor adalah semua kendaraan beroda dua atau lebih beserta gandengannya digunakan di semua jenis jalan darat dan digerakkan oleh peralatan teknik berupa motor atau peralatan lainnya yang berfungsi untuk mengubah suatu sumber daya energi tertentu menjadi tenaga gerak kendaraan bermotor yang bersangkutan, termasuk alat-alat besar yang bergerak adalah alat yang dapat bergerak atau berpindah tempat dan tidak melekatsecara permanen. (Peraturan Gubernur Nusa Tenggara Barat Nomor 31 tahun 2016).

\section{Dasar Hukum Pajak Kendaraan Bermotor}

1. Undang-undang nomor 28 Tahun 2009 Tentang Pajak Daerah dan Retribusi Daerah.

2. Perda Provinsi NTB nomor 9 Tahun 2017 tentang Pajak Daerah

3. Pergub Provinsi NTB nomor 22 Tahun 2017 Tentang Perhitungan Dasar Pengenaan PKB.

\section{Objek Pajak Kendaraan Bermotor}

Objek Pajak Kendaraan adalah kepemilikan dan atau pengeuasaan kendaraan bermotor beroda beserta gandengannya yang dioperasikan di semua jenis jalan darat dan kendaraan bermotor yang dioperasikan di air dengan ukuran isi kotor GT 5 (lima Gross Tonnage) sampai dengan GT 7 (tujuh Gross Tonnage) termasuk dalam Objek PKB adalah kepemilikan dan atau pengeuasaan kendaraan bermotoryang digunakan di semua jenis jalan darat antara lain:

1. Kawasan Bandara

2. Pelabuhan Laut

3. Perkebunan

4. Kehutanan

5. Pertanian

6. Pertambangan Industri

7. Perdagangan

8. Sarana Olahraga, dan

9. Rekreasi

\section{Pengecualian Objek Pajak Kendaraan Bermotor (PKB)}

Pada Pajak Kendaraan Bermotor tidak semua kepemilikan dan atau penguasaan kendaraan bermotor dikenakan pajak. Beberapa pengecualian yang tidak termasuk yaitu antara lain:

1. kereta api;

2. kendaraan bermotor yang semata-mata digunakan untuk keperluan pertahanan dan keamanan negara;

3. kendaraan bermotor yang dimiliki dan/atau dikuasai kedutaan, konsulat, perwakilan negara asing dengan asa timbale balik dan lembaga-lembaga internasional yang memperoleh fasilitas pembebasan pajak dari Pemerintah; dan

4. kendaraan bermotor yang dimiliki dan/atau dikuasai oleh pabrikan atau importir yang semata-mata disediakan untuk keperluan pameran dan tidak untuk dijual. 


\section{Subjek Pajak Kendaraan Bermotor (PKB) dan Wajib Pajak Kendaraan Bermotor.}

Pasal 4 UU Nomor 28 Tahun 2009 mengatur bahwa subjek pajak kendaraan bermotor adalah orang pribadi atau badan yang memiliki dan atau menguasai kendaraan bermotor. Wajib Pajak Kendaraan Bermotor adalah orang Pribadi atau Badan yang memiliki kendaraan bermotor.Bagi wajib pajak yang Berupa suatu Badan atau kewajiban perpajakannya diwakili oleh pengurus atau kuasa daribadan tersebut.

\section{Dasar Pengenaan Pajak Kendaraan Bermotor}

Dasar pengenaan Pajak Kendaraan Bermotor yaitu:

1. Dasar pengenaan Pajak Kendaraan Bermotor adalah hasil perkalian dar 2 (dua) unsur pokok:

a. Nilai Jual Kendaraan Bermotor; dan

b. bobot yang mencerminkan secara relative tingkat kerusakan jalan dan/atau pencemaran lingkungan akibat penggunaan Kendaraan Bermotor.

2. Dasar pengenaan pajak khusus untuk kendaraan bermotor yang digunakan di luar jalan umum, termasuk alat-alat berat dan alat-alat besar serta kendaraan di air, adalah Nilai Jual Kendaraan Bermotor.

3. Nilai Jual Kendaraan Bermotor sebagaimana dimaksud pada angka (1) huruf a dan angka (2), ditentukan berdasarkan Harga Pasaran Umum atas suatu Kendaraan Bermotor.

a. koefisien sama dengan 1 (satu) berarti kerusakan jalan dan/atau pencemaran lingkungan oleh penggunaan kendaraan bermotor tersebut dianggap masih dalam batas toleransi, dan

b. koefisien lebih besar dari 1 (satu) berarti penggunaan kendaraan bermotor tersebut dianggap melewati batas toleransi.

\section{Pengertian Pendapatan Asli Daerah}

Pendapatan Asli Daerah (PAD) adalah segenap pemasukan atau penerimaan yang masuk ke dalam kas daerah, diperoleh dari sumber-sumber dalam wilayahnya sendiri, dipungut berdasarkan Peraturan Daerah sesuai peraturan perundangundangan yang berlaku dan dipergunakan untuk keperluam daerah. Oleh karena itu, tiap-tiap daerah harus mengupayakan agar dapat dipungut seintensif mungkin.

\section{Pengertian Intensifikasi}

Intensifikasi merupakan sebuah bentuk dari cara untuk melakukan peningkatan dari adanya sebuah hasil produksi dengan cara melakukan peningkatan kemampuan guna untuk melakukan pemaksimalan dari produktivitas berbagaimacam bentuk faktor produksi.

\section{Intensifikasi Pajak}

Intensifikas Pajak adalah kegiataan yang dilakukan untuk menambah jumlah penerimaannya dari wajib pajak yang sudah terdaftar sebagai wajib pajak daerah. Intensifikasi pajak juga merupakan tahapan lanjutan, yang mana kegiatan tersebut mengoptimalisasi penggalian penerimaan pajak terhadap subjek serta objek pajak yang telah tercatat atau terdaftar dalam administrasi: (https://www.onlinepajak.com/ekstensifikasi-pajak-dan-intensifikasi-pajak)

\section{Penegakan Hukum:}

1. Penyampaian Surat Teguran.

2. Pelaksanaan Juru Sita.

3. Operasi Gabungan ditiap uptb. 


\section{HASIL PENELITIAN DAN PEMBAHASAN}

\section{Intensifikasih Pajak Kendaraan Bermotor (PKB) dalam rangka meningkatkan Pendapatan Asli Daerah (PAD) pada kantor Badan Pengelolaan Pendapatan Asli Daerah (BAPPENDA) Provinsi NTB}

Intensifikas Pajak adalah kegiataan yang dilakukan untuk menambah jumlah penerimaannya dari wajib pajak yang sudah terdaftar sebagai wajib pajak daerah. Intensifikasi pajak juga merupakan tahapan lanjutan, yang mana kegiatan tersebut mengoptimalisasi penggalian penerimaan pajak terhadap subjek serta objek pajak yang telah tercatat atau terdaftar dalam administrasi: (https://www.onlinepajak.com/ekstensifikasi-pajak-dan-intensifikasi-pajak)

Strategi yang digunakan dalam meningkaant PAD adalah sebagai berikut:

1. Menyiapkan data objek aktif tiap upt.

2. Menyiapkan aplikasi untuk monitoring data aktif.

3. Melakukan monitoring dan pengendalian terhadap data aktif terhadap objek kendaraan bermotor.

4. Menyampaikan pemberitahuan pajak melalui surat maupun elektronik

5. Obyek yang tidak melakukan daftar ulang setelah jatuh tempo, agar diterbitkan surat teguran

6. Menyusun strategi kinerja bagi seluruh staf berdasarkan jumlah surat teguran yang telah dibagi per wilayah

7. Mengoptimalisas fungsi aplikas dalam melakukan update data potensi, penerbitan surat pemberitahuan dan surat teguran

8. Melakukan monitoring dan pengendalian terhadap data aktif secara rutin

9. Pelayanan:

a. Peningkatan Kualiatas Layanan

b. Peningkatan Akses dan Jam Layanan

c. Operasi Gabungandi tiap uptb.

Pedukung intensifikasi dalam menigkatkan PAD:

1. Petugas bappenda mendatangi rumah wajib pajak yang menunggak membayar pajaknya.

2. Samsat delivery

3. Operasi gabungan di tiap uptb

4. Denda keterlambatan dihapusakan bagi yang terlambat membayar pajak.

5. Surat teguran

6. Meningkatkan akses dan jam layanan.

7. Samsat keliling.

8. Samsat zerowaste.

\section{Pencapaian Target Pajak Daerah Yang Di Pungut Dari Pajak Kendaraan Bermotor (PKB)}

Target adalah sasaran batas ketentuan dan sebagainya yang telah di tetapkan untuk dicapai, sedangkan pencapaian/ realisasi merupakan penerimaan sesungguhnya yang diperoleh oleh pemerintah dalam tahun pajak bersangkutan. Target penerimaan Pajak Kendaraan Bermotor di BAPPENDA Provinsi NTB setiap tahunnya ditetapkan oleh Pimpinan BAPPENDA. Target yang ditetapkan dan realisasi yang dicapai setiap tahun dari Tahun 2015-2019 seperti terlihat pada tabel berikut. 
Tabel 4. Target dan Realisasi serta Capaian Pajak Kendaraan Bermotor di Provinsi NTB tahun 2015-2019

\begin{tabular}{c|c|c|c}
\hline Tahun & Target & Realisasi & Capaian \\
\hline 2015 & $230,838,000,000$ & $240,153,372,762$ & $104.04 \%$ \\
\hline 2016 & $248,153,000,000$ & $269,187,973,631$ & $108.48 \%$ \\
\hline 2017 & $311,893,723,935$ & $324,423,070,254$ & $104.02 \%$ \\
\hline 2018 & $362,500,000,000$ & $389,092,415,685$ & $107.34 \%$ \\
\hline 2019 & $407,690,000,000$ & $437,162,593,976$ & $107.23 \%$ \\
\hline
\end{tabular}

sumber: Kantor Bappenda Provinsi NTB, 2020

Berdasarkan tabel diatas dapat diketahui bahwa target penerimaan PKB dari tahun ke tahun mengalami peningkatan yaitu sebesar Rp. 230,838,000,000 pada tahun 2015 dan meningkat menjadi Rp. 407,690,000,000 pada Tahun 2019 atau terjadi peningkatan selama 5 tahun 43,37 \% Sedangkan Realisasi PKB dari tahun ke tahun juga mengalami peningkatan yaitu Rp. 240,153,372,762 pada tahun 2015 dan meningkat menjadi Rp. 437,162,593,976 pada Tahun 2019 dan terjadi peningkatan selama 5 tahun berturut-turut sebesar $45,06 \%$.

\section{SIMPULAN}

Berdasarkan pembahasan, dapat di tarik bebrapa kesimpulan sebagai berikut:

1. Intensifikasih Pajak Kendaraan Bermotor (PKB) dalam rangka meningkatkan Pendapatan Asli Daerah (PAD) pada kantor Badan Pengelolaan Pendapatan Asli Daerah (BAPPENDA) Provinsi NTB dilakukan dengan menempuh beberapa: 1) Petugas bappenda mendatangi rumah wajib pajak yang menunggak membayar pajaknya 2) Samsat delivery 3) Operasi gabungan di tiap uptb 4) Denda keterlambatan dihapusakan bagi yang terlambat membayar pajak 5) Surat teguran

2. Meningkatkan akses dan jam layanan 7) Samsat keliling 8) Samsat zerowaste. Pencapaian target pajak daerah yang di pungut dari Pajak Kendaraan Bermotor (PKB) oleh Bappenda Provinsi NTB dari tahun 2016-2020 melebihi target yang ditetapkan yaitu rata-rata capaiannya 108,01 persen dengan kisaran capaian antara 104,02 persen sampai dengan 112,99 persen.

\section{DAFTAR PUSTAKA}

Fajar Billy Sandi, 2020. Memahami Peranan Ekstensifikasi Pajak \&Intensifikasi Pajak dihttps://www.onlinepajak.com/ekstensifikasipajak-dan-intensifikasi-pajak

Mastersite. 2016. Forum Pajak Indonesia di https://forumpajak.org/pajak-kendaraanbermotor

Mardiasmo. 2011, perpajakan, edisi revisi, Andi, Yogyakarta Soemitro, Rochmat, Dasardasar Hukum Pajak dan Pajak Pendapatan 1994, PT Eresco, Bandung1992.

Soemitro, Rochmat, Asas dan Dasar Perpajakan 1 dan 2, PT Eresco,Bandung 1992.

Waluyo. 2007. Perpajakan Indonesia. Buku satu dan dua. Jakarta: Penerbit Salemba Empat. 